\title{
Anti-Cancer Effect of Tacrine-Coumarin Derivatives on Diverse Human and Mouse Cancer Cell Lines
}

\author{
Zuzana Solárová, ${ }^{1}$ Martin Kello, ${ }^{1}$ Slávka Hamulaková, ${ }^{2}$ \\ Ladislav Mirossay ${ }^{1}$ and Peter Solár ${ }^{3, *}$ \\ ${ }^{1}$ Institute of Pharmacology, Faculty of Medicine, P. J. Šafárik University in Košice, SK-04154 Košice, Slovak Republic \\ ${ }^{2}$ Department of Organic Chemistry, Institute of Chemistry, Faculty of Science, P. J. Šafárik University in Košice, \\ SK-04154 Košice, Slovak Republic \\ ${ }^{3}$ Institute of Medical Biology, Faculty of Medicine, P. J. Šafárik University in Košice, SK-04154 Košice, Slovak Republic \\ * Corresponding author: E-mail: peter.solar@upjs.sk
}

Received: 04-06-2018

\begin{abstract}
Acridine derivatives were first used as antibacterial and antiparasitic agents, later as antimalarial and anti-HIV drugs, and now as potentially anticancer agents due to their high cytotoxic activity. Due to their serious adverse effects, new synthetic derivatives were introduced and tested based on modified naturally occurring substances, such as acridone derivatives, which also exhibit potential anti-tumor activity. Most of them are DNA-damaging substances, causing relatively strong and selective destruction of tumor cells. We have tested in vitro anti-proliferative effects of newly-synthesized tetrahydroacrid derivatives, namely tacrine-coumarin hybrid molecules, on various human and mouse cancer cell lines. Our results showed that tacrine-coumarin hybrids with seven, eight, and nine methylene groups in spacer reduce proliferation of cancer cells. A hybrid with nine methylene groups had the most significant anti-cancer effect.
\end{abstract}

Keywords: Tacrine-coumarin hybrid molecules; cancer cells; antiproliferative effects

\section{Introduction}

Coumarin and coumarin derivatives are well known anticancer agents. The anticancer activity of coumarin derivatives, 3-, 4-, 7-, 8- substituted biscoumarins and fused coumarins, has been described according to the type and position of the side chain of the coumarin core structure. ${ }^{1}$ The number, location, and length of the side chain have important effects on anti-tumor activities. ${ }^{2}$ Fig. 1 shows the chemical structure of 4 -substituted coumarins that reveal interesting anti-cancer activity.

Basanagouda et al. ${ }^{3}$ synthesized a new series of iodinated-4-aryloxymethyl coumarin derivatives 1 (Fig. 1). These compounds were screened for their in vitro anticancer activity against two cancer cell lines, MDA-MB human adenocarcinoma mammary gland and A-549 human lung carcinoma. The compounds in which the chlorine was in C- 6 and C-7 position on coumarin ring and iodine was in C-4 position on phenoxy moiety exhibited significant anti-cancer activity $(\mathrm{MIC}=1.56 \mu \mathrm{g} / \mathrm{mL}){ }^{3}$ Bana et al. ${ }^{4}$ designed and synthesized a novel couma- rin-quinone inhibitor 2 (SV37, Fig. 1), the structure of which is based on both coumarin and quinone moieties as a potent CDC25 inhibitor. An analytical in vitro approach shows that this compound efficiently inhibits all three purified human CDC25 isoforms, CDC25A, B, and C, with $\mathrm{IC}_{50}$ between 1 and $9 \mu \mathrm{M}$. Moreover, 2 isoforms had superior antiproliferative activity against MCF-7 and MDAMB-231 cells $\left(\mathrm{IC}_{50}=1-11 \mu \mathrm{M}\right)$ versus hTERT-HME1 $\left(\mathrm{IC}_{50}=18 \mu \mathrm{M}\right) .{ }^{4}$ Puttaraju et al. ${ }^{5}$ designed and synthesized a new series of coumarin substituted dihydrobenzo[4,5]imidazo[1,2-a]pyrimidin-4-ones derivatives 3 . The coumarin derivative with $i$ - $\mathrm{Pr}$ in C-3 position on dihydrobenzo[4,5]imidazo[1,2-a]pyrimidin-4-one and chlorine in C-6 position on coumarin ring was found to be the most potent cytotoxic compound (88\%) against Dalton's Ascitic Lymphoma cell line. ${ }^{5}$

Sequences of 4-(1,2,3-triazol-1-yl)coumarin derivatives 4 were synthesized and their anti-cancer activities against human cancer cell lines, including human breast carcinoma MCF-7 cell, colon carcinoma SW480 cell, and lung carcinoma A549 cell, were subsequently studied in 
<smiles>[R]c1ccc2oc(=O)cc(COc3ccccn3)c2c1</smiles>

$\mathrm{R}=6-\mathrm{Cl}, 7, \mathrm{Cl}, 6-\mathrm{Br}$

1<smiles>COc1ccc2c(CSC3=CC(=O)c4ccccc4C3=O)cc(=O)oc2c1</smiles><smiles>CCCc1cc(=O)n2c3ccccc3n(Cc3cc(=O)oc4ccc(Cl)cc34)c2n1</smiles><smiles>[2H]</smiles>

2<smiles>COC</smiles>

O 3<smiles>COc1ccc2c(-n3cc(COc4ccc(F)cc4)nn3)cc(=O)oc2c1</smiles>

4<smiles>O=c1oc2ccccc2c(-c2ccc(OCCF)cc2)c1-c1ccccc1</smiles><smiles></smiles>

3

$\mathrm{X}=\left(\mathrm{CH}_{2}\right)_{1,8}$<smiles>Cc1cccc(C)c1</smiles><smiles></smiles><smiles>CN1CCCCC1</smiles>

Figure 1. Structures of 4-substituted coumarin derivatives 1-4 and bis-coumarines 5, 6 revealing anticancer activities

vitro. Among them, 4-(4-(4-fluorophenoxy) methyl)1,2,3-triazol-1-yl)-7-methoxycoumarin 4 exhibited excellent broad spectrum anti-cancer in vitro activity against MCF-7, SW480, and A549 $\left(\mathrm{IC}_{50}=5.89,1.99\right.$, and $0.52 \mu \mathrm{M}$, respectively). ${ }^{6}$

In general, the dimeric coumarin tends to show greater efficacy against cancer cells compared to the monomeric one. ${ }^{2}$ Some bis-coumarine dimers with the anti-cancer activity are shown in Fig. 1. Novel bis-coumarin polysulfides as di-, tri-, and tetrasulfides $\mathbf{5}$ were synthesized and tested in the HCT116 colorectal cancer cell line to assess their ability to induce cell growth inhibition and apoptosis. The coumarin polysulfides effectively reduced cell viability (around 50\%) in a concentration and time dependent manner and reduced cell viability more efficiently compared to the corresponding diallyldisulfide. ${ }^{7}$
Tan et al. $^{2}$ designed and synthesized novel dimers of triphenylethylene-coumarin hybrid $\mathbf{6}$ containing one amino side chain. These dimeric substances were subjected to anti-proliferative tests against four tumor cell lines, MCF-7, A549, K562, and HeLa, and exhibited significant anti-proliferative activity at $\mathrm{IC}_{50}$ concentrations approaching $10 \mu \mathrm{M}$.

Since the anti-cancer activity of hybrids in which the coumarin ring is connected with tacrine has not yet been reported, based on the knowledge that coumarin functional groups as well as tetrahydroacridine derivatives have anti-tumor effects, we decided to test such effects using newly synthesized tacrine-coumarin hybrids 7a-g (Fig. 2 ). Both the synthesis and the biological activity of relevant tacrine-coumarin hybrids, except for anti-cancer ones, have already been published. ${ }^{8}$ 
<smiles>[X][M]Nc1c2c(nc3ccccc13)CCCC2</smiles>

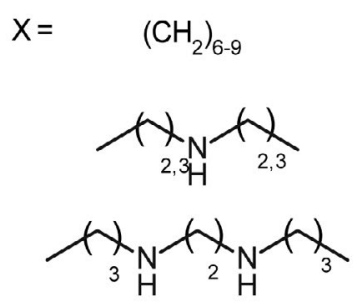

$7 a-g$

Figure 2. Structures of tacrine-coumarin hybrids $7 \mathrm{a}-\mathrm{g}$

Little work has been done on the anti-tumor effects of tacrine. However, published results clearly demonstrated that only high concentration of tacrine can induce apoptosis via lysosome- and mitochondrial-dependent pathway in HepG2 cells. ${ }^{9,10}$ On the other hand, despite high concentration, tacrine did not show any cytotoxic effect on the promyelocytic leukemia HL-60 cell line. ${ }^{11}$ In this study, we decided to test the anti-cancer effects of tacrine-coumarin hybrids on highly invasive (4T1), less invasive (A549, HCT) and non-invasive (MCF-7) cell lines. To reinforce the hypothesis of different effects of tacrine-coumarin hybrids on cancer cells compared to normal ones, we compared human cancer cell lines (MCF-7, A549, HCT) with normal HUVEC cells and mouse tumor cell line $4 \mathrm{~T} 1$ with the normal mouse cells NMuMG.

\section{Experimental}

\section{1. Cell lines and Cell Culture}

Human colorectal carcinoma HCT116 (HCT), human breast adenocarcinoma MCF-7, human A549 lung carcinoma, and mouse mammary carcinoma $4 \mathrm{~T} 1$, as well as non-cancer mouse mammary gland cells NMuMG and human endothelial cells isolated from umbilical vein HUVEC, were used in our experiments. The HCT, MCF-7, and $4 \mathrm{~T} 1$ cell lines were cultured in RPMI medium (Sigma-Aldrich, St. Louis, MO, USA), A549 and NMuMG in DMEM medium with high glucose $(4.5 \mathrm{~g} / \mathrm{l})$, and L-glutamine (GE Healthcare, Little Chalfont, UK) and HUVEC cells in HMEC medium (Sigma-Aldrich) with added vascular endothelial growth factor and bovine fibroblast growth factor. All media contained $10 \%$ fetal bovine serum (Thermo Fisher Scientific, Inc., Waltham, MA, USA) and antibiotics (Sigma-Aldrich), except 4T1 and NMuMG cells, which did not contain antibiotics. The cells were incubated at $37{ }^{\circ} \mathrm{C}$ in a humidified $5 \% \mathrm{CO} 2(\mathrm{v} / \mathrm{v})$ atmosphere. Dr. Hamulaková of the Institute of Chemistry, Faculty of Science, Pavol Jozef Šafárik University in Košice, synthesized Tacrine-coumarin derivatives.

\section{2. MTT Assay}

HCT, MCF-7, A549, 4T1, NMuMG, and HUVEC cells were seeded into 96-well cell culture plates at a density of $5 \times$ $10^{3}$ per well. MTT (3-(4.5-dimethylthiazol-2-yl)-2.5-diphenyl tetrazolium bromide; Sigma-Aldrich Co.) was added at the final concentration of $0.2 \mathrm{mg} / \mathrm{ml}$ after $72 \mathrm{~h}$ incubation at the concentration ranging from 0.001 to $10 \mu \mathrm{M}$ of tacrine-coumarin hybrid molecules [Fig. 1; synthesized and characterized by Hamulaková et al., ${ }^{8}$ followed by $4 \mathrm{~h}$ incubation at $37^{\circ} \mathrm{C}$ and solubilization of MTT-formazan product using 3.3\% sodium dodecyl sulphate (Sigma-Aldrich Co.)]. The absorbance was measured using a universal microplate reader (FLUOstar Optima, BMG Labtechnologies GmbH, Offenburg, Germany) and expressed as a percentage of the dye extracted from untreated control cells [ $(\mathrm{OD}$ value of treated cells/mean OD value of control cells) $\times 100 \%]$.

\section{3. Cell cycle Analysis}

Flow cytometric DNA analysis was used to estimate the distribution of monitored cancer and normal cells at different stages of the cell cycle. All the cell lines were harvested after $72 \mathrm{~h}$ incubation at $10 \mu \mathrm{M}$ concentration of $1 \mathrm{~b} / \mathrm{sh} \_7,1 \mathrm{c} / \mathrm{sh} \_8$ or $1 \mathrm{~d} / \mathrm{sh} \_9$, washed with phosphate-buffered saline (PBS), fixed in $70 \%$ ice cold ethanol, and stored at $4{ }^{\circ} \mathrm{C}$ for $24 \mathrm{~h}$. Fixed cells were centrifuged, washed with PBS, stained with staining solution $[20 \mu \mathrm{g} / \mathrm{mL}$ propidium iodide, $137 \mu \mathrm{g} / \mathrm{mL}$ RNAse A, and $0.1 \%$ Triton X-100 (Sigma-Aldrich Co.) in PBS] in the dark for $30 \mathrm{~min}$, and measured with a flow cytometer (FACSCalibur, Becton Dickinson, San Diego, CA, USA). For each sample, a minimum of $15 \times 10^{3}$ cells was evaluated and analysed using FlowJo software (FLOWJO, LLC; Ashland, OR, USA). Cells characterized by DNA content lower than diploid (subG0/G1 population) were considered as apoptotic cells.

\section{4. IncuCyte ZOOM System}

Experiments were performed using an IncuCyte ZOOM system (Essen BioScience, Ann Arbor, MI, USA), 
which consists of a microscope gantry that resides in a humidified incubator at $37^{\circ} \mathrm{C}$ and $5 \% \mathrm{CO}_{2}$, and a networked external controller hard drive that gathers and processes image data. The cells were seeded in 96-well plates in sextuplicates at 5000 cells/well (as $100 \mu \mathrm{l}$ cell suspension/well) and placed in the IncuCyte ZOOM system. After attachment $(24 \mathrm{~h})$, the cells were treated with $1 \mathrm{~b} / \mathrm{sh} \_7,1 \mathrm{c} / \mathrm{sh} \_8$ a 1d/sh_9 test substances (dissolved in media). The cells growing in media without tested substances were used as controls. The IncuCyte zooM system automatically monitored the cell confluence in each well through a $4 \mathrm{X}$ objective (Nikon) every $2 \mathrm{~h}$ up to $130 \mathrm{~h}$ of the substance treatment. The experiment was performed two times.

4T1

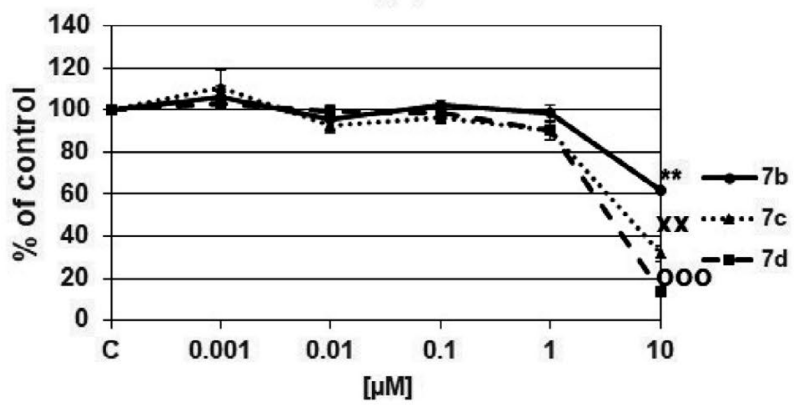

HCT

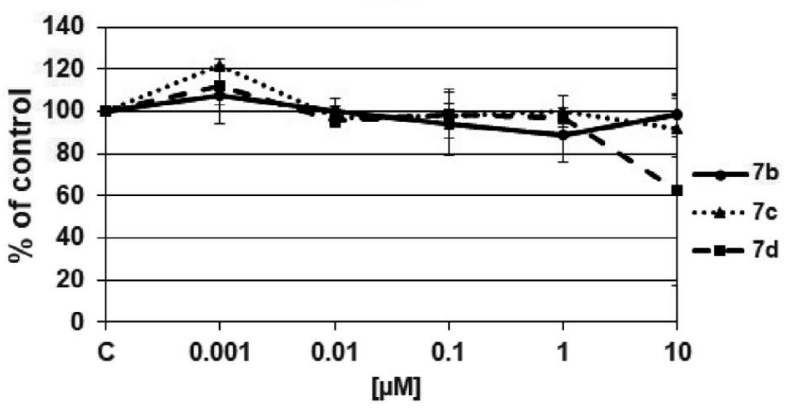

NMuMG

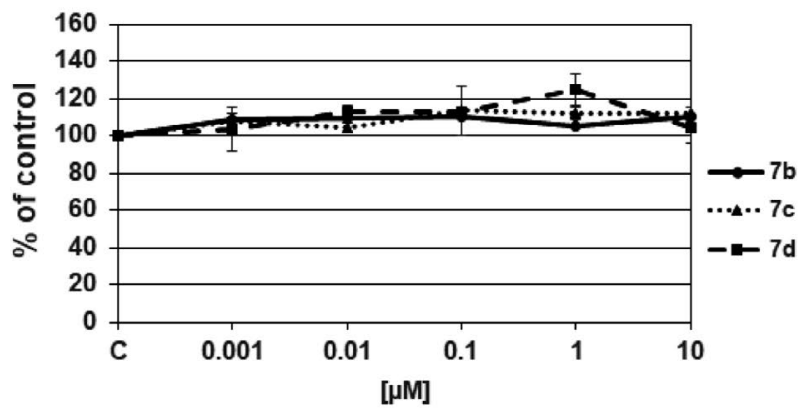

\section{5. Statistical Analysis}

Data were analyzed using one-way ANOVA followed by Tukey's multiple comparison tests in ORIGIN analysis software (OriginLab Co., Northampton, MA, USA).

\section{Results and Discussion}

In the view of biological significance of tacrine and coumarin derivatives, potential cytotoxic and/or anti-cancer activities of tacrine-coumarin heterodimers $7 \mathbf{a}-\mathbf{g}$ were tested using tumor as well as normal cell lines. In this re-
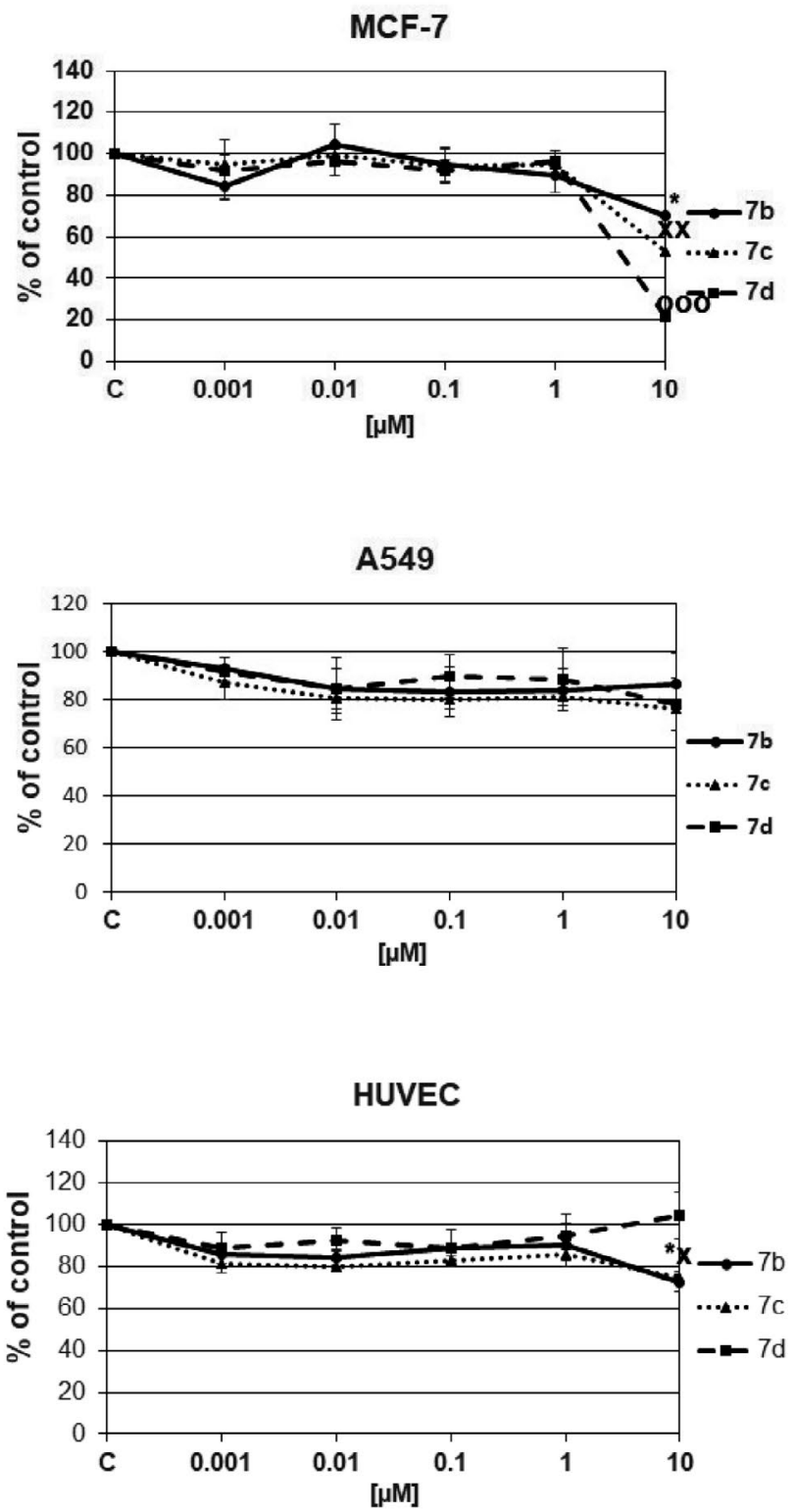

Figure 3. The effect of 7b-d tacrine-coumarine derivatives on the metabolic activity of 4T1, MCF-7, HCT, A549, NMuMG, and HUVEC cells. The metabolic activity of 4T1, MCF-7, HCT, A549, NmuMG, and HUVEC cells was analyzed by MTT assay after their treatment with 7b-d derivatives for $72 \mathrm{~h}$. Data are expressed as mean \pm SEM (\% of control) across three independent experiments. The statistical significance is designated as follows: ${ }^{*} \mathrm{p}<0.05$ and $^{* *} \mathrm{p}<0.01$ for $7 \mathrm{~b}$ derivative vs. control $(\mathrm{C}){ }^{\mathrm{x}} \mathrm{p}<0.05$ and ${ }^{\mathrm{xx}} \mathrm{p}<0.01$ for $7 \mathrm{c}$ derivative vs. $\mathrm{C}$; and ${ }^{\circ 00} \mathrm{p}<0.001$ for $7 \mathrm{~d}$ derivative vs. C. 
gard, the responses of 4T1 (mouse mammary carcinoma), MCF-7 (human breast adenocarcinoma), HCT116 (human colorectal carcinoma), A549 (human lung carcinoma), NMuMG (normal mouse mammary gland cells), and HUVEC (human endothelial cells isolated from umbilical vein) were compared. Application of compounds $7 \mathbf{a}$ and 7e-g did not show toxic effects on either cancer or normal cells (not shown). Thus, only $\mathbf{7 b}-\mathbf{d}$ compounds were included in further analysis. The concentrations of $\mathbf{7 b}$-d hybrids used in both cell cycle as well as cell proliferation assays were derived based on the extensive screening of the cell metabolism and/or cell growth response (MTT). The concentrations of $\mathbf{7 b} \mathbf{b}-\mathbf{d}$ derivatives inhibiting $50 \%\left(\mathrm{IC}_{50}\right)$ of the metabolic activity and/or the cell growth are shown in supplementary data (Table S01). Based on $\mathrm{IC}_{50}$ values, the synthesized compounds showed moderate to significant activity in the $\mu \mathrm{M}$ range from 5.7 to $>100 \mu \mathrm{M}$. The effect

4T1

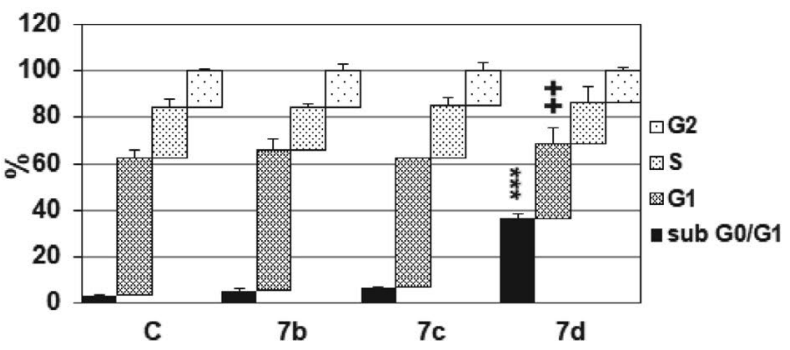

HCT

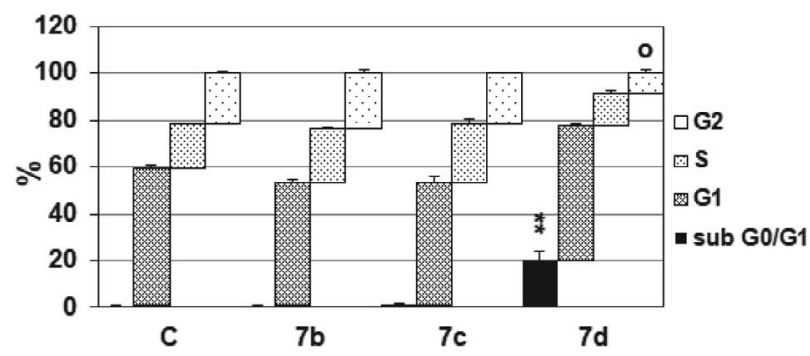

NMuMG

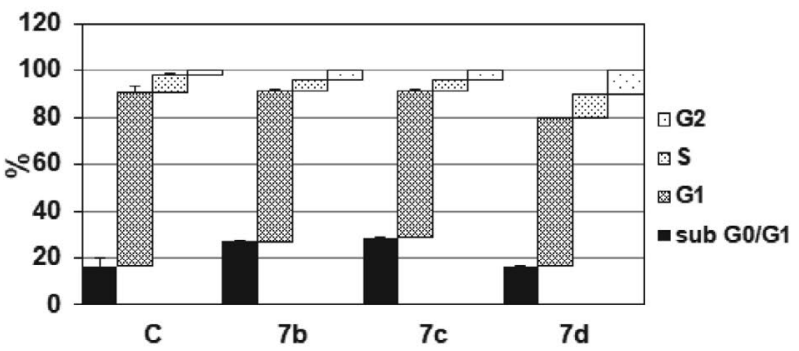

of chain lengths linking tacrine and coumarin skeleton was examined. Compounds $\mathbf{7 d}$ and $\mathbf{7} \mathbf{c}$ showed significant anti-metabolic activity against $4 \mathrm{~T} 1$ cell lines, with $\mathrm{IC}_{50}$ values of $5.7 \mu \mathrm{M}$ and $7.0 \mu \mathrm{M}$, respectively (Fig. 3). The compound $\mathbf{7 d}$ also showed promising activity against MCF-7 cell line, with $\mathrm{IC}_{50}$ value of $6.0 \mu \mathrm{M}$ (Fig. 3). Furthermore, derivatives $\mathbf{7 b}$ and $\mathbf{7} \mathbf{c}$ showed stronger effect compared to 7d in the reduction of HUVEC cells metabolism (Fig. 3). Interestingly, based on MTT results, HCT, A549, and NMuMG cells did not respond to the effect of $\mathbf{7 b - d}$ compounds (Fig. 3). These results demonstrate that the length of the alkyl spacer influences, at least to some degree, the metabolic activity and/or the cell growth of breast cancer cell lines $4 \mathrm{~T} 1$ and MCF-7.

Flow cytometric analysis was performed to evaluate the cell cycle progression in all monitored cell lines after their incubation with $\mathbf{7 b}$-d derivatives at the concentration
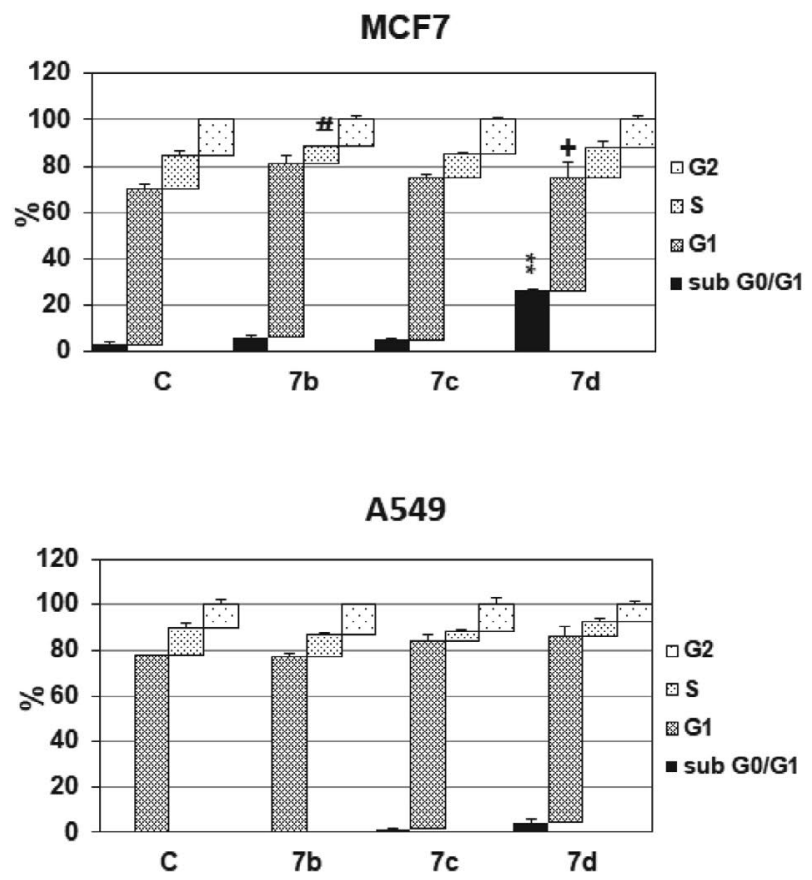

HUVEC

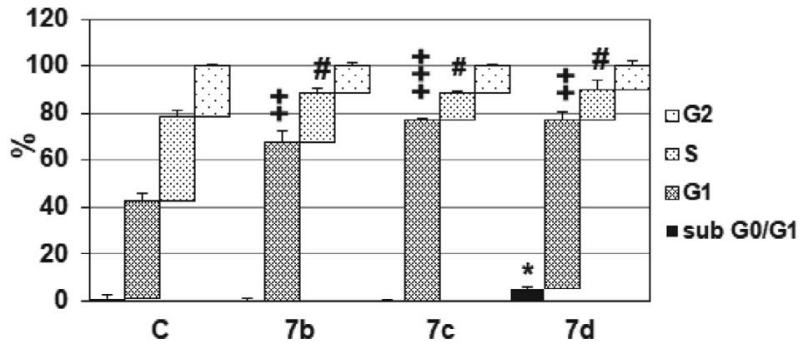

Figure 4. The cell cycle distribution of 4T1, MCF-7, HCT, A549, NmuMG, and HUVEC cells after treatment with 7b-d tacrine-coumarine derivatives. 4T1, MCF-7, HCT, A549, NmuMG, and HUVEC cells were treated with 7b-d derivatives at the concentration of $10 \mu \mathrm{M}$ for $72 \mathrm{~h}$. Data from the three independent experiments are expressed as mean \pm SEM. The statistical significance is designated as follows: ${ }^{*} p<0.05,{ }^{* *} p<0.01,{ }^{* * *} p<0.001$ for sub G0/G1 fraction of 7b-d vs. control cells (C); + p < 0.05, ++ p $<0.01,+++p<0.001$ for G1 fraction of 7b-d vs. C; \# $p<0.05$ for S fraction of $7 \mathrm{~b}-\mathrm{d}$ vs. $\mathrm{C}$ and ${ }^{\circ} \mathrm{p}<0.05$ for $\mathrm{G} 2$ fraction of $7 \mathrm{~b}-\mathrm{d}$ vs. C. 
of $10 \mu \mathrm{M}$. Data showed that $\mathbf{7 d}$ hybrid had the most significant effect on the cell cycle progression (Fig. 4). This compound increased apoptotic sub G0/G1 population in 4T1, MCF-7, HCT, and HUVEC cells and reduced G1 population in 4T1 and MCF-7. On the other hand, all derivatives $\mathbf{7 b}$-d increased $\mathrm{G} 1$ and decreased $S$ population of HUVEC cells (Fig. 4). Without the change in the cell cycle progression stayed cancer A549 and normal NMuMG cells (Fig. 4).

The synthesized compounds $\mathbf{7 b}$-d were also evaluated for their in vitro anti-proliferative activity monitored by IncuCyte system. The most sensitive tumor cell line was the MCF-7 (Supplementary data, Fig. S01), for which the decrease of proliferative activity depended on the increase of carbon number in the tested compounds $7 \mathbf{b}-\mathbf{d}$. HCT (Supplementary data, Fig. S02) and 4T1 (Supplementary data, Fig. S03) tumor cell lines showed lower sensitivity to the tested hybrids $\mathbf{7 b}-\mathbf{d}$ with similar responses. On the other hand, A549 tumor cells (Supplementary data, Fig. S04) proved to be the most resistant, with proliferation not significantly different from other cell lines after the administration of the above-mentioned three tacrine-coumarin derivatives. In addition, HUVEC cells (Supplementary data, Fig. S05) responded only to the $\mathbf{7 d}$ derivative while the normal mouse mammary gland cells of NMuMG (Supplementary data, Fig. S06) did not demonstrate a decrease in proliferation after the application of the tested substances.

Among the synthesized compounds, the tacrine-coumarin heterodimer $\mathbf{7 d}$ with nine methylene groups between the two amino groups in the side chain exhibited the greatest efficiency. According to the results, in the case of tacrine-coumarin heterodimers 7e-g with longer side chains, replacing some methylene groups with amine moiety dramatically decreased the anti-cancer activity.

Emami et al. ${ }^{1}$ have also confirmed that the anti-proliferative activity depends on the presence of the quinone skeleton. The structure-activity relationship of compound 4-(4-((4-fluorophenoxy)methyl)-1,2,3-triazol-1-yl)-7-methoxycoumarin 4 (Fig. 1) suggested that - C-4 position of 1,2,3-triazole core is the optimal position for $\mathrm{CH}_{2}-\mathrm{O}$ bridge because of its bioactivity. A hydrogen bond acceptor at C-4 position of phenyl is indispensable for the improvement of the potency while a hydrogen bond acceptor at C-7 position of coumarin can positively contribute to the activity. ${ }^{6}$

For bis-coumarin derivatives possessing one amino side chain 6 (Fig. 1), the length of the linker (dicarboxylic acid) had profound effects on their anti-proliferative activities. Compounds linked by the malonic amide (three carbons) showed the best anti-proliferative activities against MCF-7, A549, K562, and Hela cell lines; however, as the linker increased to five, six, or ten carbons, their anti-proliferative activities clearly decreased. In this regard, the incorporation of the aromatic or heterocyclic ring into the chain also decreased anti-proliferative activity. ${ }^{2}$

\section{Conclusions}

In conclusion, structural modification of natural substances can yield new analogues, the biological efficacy of which can be higher compared to that of the parent compounds. In our experimental study, we found that tacrine-coumarin hybrids with seven, eight, and nine methylene groups in spacer have significant anti-cancer activity in all cancer cell lines tested, with the exception of A549 cells. Indeed, hybrid with nine methylene groups had the most significant anti-cancer effect. Interestingly, the sensitivity of tumor cells was greater compared to the sensitivity of normal cells, which points to the importance of further research on the anti-tumor effects of tacrine-coumarin hybrid molecules.

\section{Conflict of Interest}

The authors declare no conflict of interest.

\section{Acknowledgment}

This study was supported (50\%) by the project Medicínsky univerzitný park v Košiciach (MediPark, Košice) ITMS: 26220220185 (95\%) funded by Operational Programme Research and Development (OP VaV2012/2.2/08-RO) (Contract No. OPVaV/12/2013).

\section{References}

1. S. Emami and S. Dadashpour, Eur J Med Chem 2015, 102, 611-30. DOI:10.1016/j.ejmech.2015.08.033

2. G. Tan, Y. Yao, Y. Gu, S. Li, M. Lv, K. Wang, H. Chen and X. Li, Bioorg Med Chem Lett 2014, 24, 2825-30.

DOI:10.1016/j.bmcl.2014.04.106

3. M. Basanagouda, V. B. Jambagi, N. N. Barigidad, S. S. Laxmeshwar, V. Devaru and Narayanachar, Eur J Med Chem 2014, 74, 225-33. DOI:10.1016/j.ejmech.2013.12.061

4. E. Bana, E. Sibille, S. Valente, C. Cerella, P. Chaimbault, G. Kirsch, M. Dicato, M. Diederich and D. Bagrel, Mol Carcinog 2015, 54, 229-41. DOI:10.1002/mc.22094

5. K. B. Puttaraju, K. Shivashankar, Chandra, M. Mahendra, V. P. Rasal, P. N. Venkata Vivek, K. Rai and M. B. Chanu, Eur J Med Chem 2013, 69, 316-22. DOI:10.1016/j.ejmech.2013.07.015

6. W. Zhang, Z. Li, M. Zhou, F. Wu, X. Hou, H. Luo, H. Liu, X. Han, G. Yan, Z. Ding and R. Li, Bioorg Med Chem Lett 2014, 24, 799-807. DOI:10.1016/j.bmcl.2013.12.095

7. N. E. Saidu, S. Valente, E. Bana, G. Kirsch, D. Bagrel and M. Montenarh, Bioorg Med Chem 2012, 20, 1584-93.

DOI:10.1016/j.bmc.2011.12.032

8. S. Hamulakova, P. Poprac, K. Jomova, V. Brezova, P. Lauro, L. Drostinova, D. Jun, V. Sepsova, M. Hrabinova, O. Soukup, P. Kristian, Z. Gazova, Z. Bednarikova, K. Kuca and M. Valko, J Inorg Biochem 2016, 161, 52-62. 
DOI:10.1016/j.jinorgbio.2016.05.001

9. C. Gao, Y. Ding, L. Zhong, L. Jiang, C. Geng, X. Yao and J. Cao, Toxicol In Vitro 2014, 28, 667-74.

DOI:10.1016/j.tiv.2014.02.001

10. M. J. Ezoulin, C. Z. Dong, Z. Liu, J. Li, H. Z. Chen, F. Hey- mans, L. Lelievre, J. E. Ombetta and F. Massicot, Toxicol In Vitro 2006, 20, 824-31. DOI:10.1016/j.tiv.2006.01.002

11. J. Janockova, J. Plsikova, J. Koval, R. Jendzelovsky, J. Mikes, J. Kasparkova, V. Brabec, S. Hamulakova, P. Fedorocko and M. Kozurkova, Bioorg Chem 2015, 59, 168-76.

DOI:10.1016/j.bioorg.2015.03.002

\section{Povzetek}

Derivati akridina so bili prvič uporabljeni kot antibakterijsko sredstvo in sredstvo proti parazitom, kasneje pa tudi kot zdravila proti malariji in HIV. Zaradi njihove visoke citotoksične dejavnosti jih uporabljajo tudi kot potencialna zdravila proti raku. Zaradi njihovih resnih škodljivih učinkov so bili uvedeni in testirani novi sintetični derivati, ki temeljijo na spreminjanju naravno prisotnih snovi, kot so derivati akridona, ki kažejo tudi potencialno aktivnost proti tumorjem. Večina od teh spojin lahko poškoduje DNA, kar povzroča razmeroma močno in selektivno uničenje tumorskih celic. Testirali smo in vitro antiproliferativne učinke na novo sintetiziranih tetrahidroakridinskih derivatov, in sicer takrin-kumarinskih hibridnih molekul. Naši rezultati so pokazali zmanjšano deljenje rakavih celic ob izpostavitvi takrin-kumari hibridom s sedem, osem in devet metilenskimi skupinami v distančniku. Najmočnejši učinek proti raku je pokazal hibrid $\mathrm{z}$ devetimi metilenskimi skupinami. 